\title{
Granule Neuron Regulation of Purkinje Cell Development: Striking a Balance Between Neurotrophin and Glutamate Signaling
}

\author{
Mary E. Morrison and Carol A. Mason \\ Departments of Pathology, and Anatomy and Cell Biology, Center for Neurobiology and Behavior, College of Physicians \\ and Surgeons, Columbia University, New York, New York 10032
}

\begin{abstract}
Granule neurons, presynaptic afferents of Purkinje cells, are potent regulators of Purkinje cell development. Purified Purkinje cells survive and differentiate poorly, whereas coculture with granule neurons enhances their survival and dendritic development. Here we investigate the role of neurotrophins in granulePurkinje cell interactions. BDNF or NT-4 improves, but NT-3 or CNTF reduces, survival of isolated Purkinje cells. When granule neurons are present, however, BDNF or NT-4 treatment leads to Purkinje cell loss. This decrease is overcome by anti-BDNF or
\end{abstract}

TrkB-IgG-blocking reagents or by CNQX, a non-NMDA glutamate receptor antagonist. Furthermore, BDNF increases the spine density on the surviving Purkinje cells. These results suggest that Purkinje cell survival and differentiation are contextdependent and require a balance between neurotrophin- and activity-dependent signaling.

Key words: Purkinje cell; granule cell; cerebellum; neurotrophins; BDNF; CNQX; spines
Afferent regulation of CNS target cell development has been studied extensively (Kandel et al., 1995). In the cerebellum, experimental and genetic ablations have identified granule neuron afferents as being more influential than olivocerebellar climbing fiber afferents for Purkinje cell survival and development (Altman and Anderson, 1972; Rakic, 1975; Privat and Drian, 1976; Sotelo and Arsenio-Nunes, 1976; Mariani et al., 1977; Hatten and Heintz, 1995). Previously, we directly tested granule neuron involvement in these processes using methods for purification of cerebellar Purkinje cells (Baptista et al., 1994) and granule neurons (Hatten, 1985; Baird et al., 1992). These experiments demonstrated that the granule neuron is a potent regulator of Purkinje cell survival and differentiation. Although purified Purkinje cells survive poorly when cultured alone, developing axons but only rudimentary dendrites (Baptista et al., 1994) (see Fig. 1A), coculture of purified Purkinje and granule cells improves survival of the Purkinje cells and triggers their dendritic differentiation (Baptista et al., 1994) (see Fig. 1C).

What molecules underlie granule neuron regulation of Purkinje cell survival and differentiation? A variety of neurotrophin and Trk mRNAs and proteins have been localized in Purkinje cells (Yan and Johnson, 1988; Cohen-Cory et al., 1989; Lindholm et al., 1993; Rocamora et al., 1993; Gao et al., 1995; Torres et al., 1995) (see Discussion) or in granule cells (Yan and Johnson, 1988; Hofer et al., 1990; Ernfors et al., 1992; Wheeler and Both-

Received Nov. 7, 1997; revised Jan. 28, 1998; accepted March 5, 1998.

This work was supported by National Institutes of Health Grant NS16951 (C.A.M.) and National Research Service Award NS09864 (M.E.M.). We thank Drs. Amy MacDermott, Wilma Friedman, Lloyd Greene, Alcmene Chalazonitis, Domenique Toran-Allerand, Riva Marcus, Anna Dunaevsky, George Yancopoulos, and Ron Lindsay for ongoing discussions and advice during the course of this work. We also thank Dr. Roger Vaughan of the Department of Public Health of Columbia University for advice on statistical analyses and Richard Blazeski for expert assistance with the photographs. Growth factors and TrkB-IgG were provided by Dr. G.

Yancopoulos (Regeneron). Anti-neurotrophin antibodies were supplied by Dr. J. Carnahan (Amgen, Thousand Oaks, CA).

Correspondence should be addressed to Dr. Carol A. Mason, Department of Pathology, College of Physicians and Surgeons, Columbia University, 630 West 168th Street, New York, NY 10032.

Copyright (C) 1998 Society for Neuroscience $\quad 0270-6474 / 98 / 183563-11 \$ 05.00 / 0$ well, 1992; Lindholm et al., 1993; Rocamora et al., 1993; Leingartner et al., 1994; Muller et al., 1994; Gao et al., 1995; Segal et al., 1995) (see Discussion), suggesting that neurotrophins may be involved in granule-Purkinje cell interactions. Moreover, neurotrophins and CNTF affect Purkinje cell development in vitro (NGF, Cohen-Cory et al., 1991; NT-3, Lindholm et al., 1993; BDNF, Mount et al., 1993; CNTF, Larkfors et al., 1994, 1996). All of these experiments, however, were performed in cultures of whole dissociated cerebellum, confounding the interpretation of which cells act or react in specific signaling events. We therefore chose to examine the role of neurotrophins in granule neuronmediated Purkinje cell development using cocultures of granule and Purkinje cells. In addition, we studied the interplay between neurotrophins and neurotransmitters in this reductionist system.

Neurotrophin signaling pathways interact with neurotransmitter systems during a number of developmental processes (for review, see Lo, 1995; Thoenen, 1995; Bonhoeffer, 1996; Henderson, 1996; Katz and Shatz, 1996; Snider and Lichtman, 1996; Schuman, 1997). These include cell survival (Cohen-Cory et al., 1991; Mount et al., 1993; Meyer-Franke et al., 1995; Riddle et al., 1995), axon arborization (Cabelli et al., 1995, 1996, 1997; Galuske et al., 1996; Prakash et al., 1996), dendritic differentiation (McAllister et al., 1995, 1997), synaptic transmission (Lohof et al., 1993; Levine et al., 1995; Stoop and Poo, 1996), and plasticity (Kang and Schuman, 1995, 1996; Figurov et al., 1996; Patterson et al., 1996; Akaneya et al., 1997; Schuman, 1997). Despite these difficult and elegant analyses, the cell types that mediate the collaboration of neurotrophin- and activity-dependent processes are largely unknown.

This study shows that neurotrophin action depends on the context in which a cell is growing. Survival of purified Purkinje cells cultured alone is increased by BDNF or NT-4, but surprisingly, survival of Purkinje cells cultured with granule neurons, their normal presynaptic afferents, is diminished by the same treatment. This neurotrophin-induced death is blocked by a nonNMDA receptor antagonist, revealing that a precise balance 
between the neurotrophin and neurotransmitter signaling systems is required for Purkinje cell survival.

\section{MATERIALS AND METHODS}

Animals. Experiments were performed with $\mathrm{C} 57 \mathrm{BL} / 6 \mathrm{~J}$ mice from a timed pregnancy breeding colony with the plug date considered embryonic day $0(\mathrm{E} 0)$. For mixed cerebellar cultures or for purified Purkinje cells, cerebella were taken from animals on the first day after birth, designated postnatal day $0(\mathrm{P} 0)$. For any single Purkinje cell purification experiment, $30 \mathrm{P} 0$ pups were used, but occasionally it was necessary to use some P1 pups as well. Granule neurons were purified from pups on postnatal day 4.

Culture media and substrates. The composition of the media differed somewhat from that published previously (Baptista et al., 1994). Serumfree medium was composed of Eagle's basal medium with Earle's salts (Life Technologies, Gaithersburg, MD) supplemented with bovine serum albumin $(10 \mathrm{mg} / \mathrm{ml}$; A-9418, Sigma, St. Louis, MO), glutamine (2 mm; Life Technologies), glucose (32 mM), penicillin-streptomycin (29 U/ml each; Life Technologies), and Sigma I-1884 supplement (1:100 dilution, giving final concentrations of $5 \mu \mathrm{g} / \mathrm{ml}$ insulin, $5 \mu \mathrm{g} / \mathrm{ml}$ transferrin, and 5 $\mathrm{ng} / \mathrm{ml}$ sodium selenite). Serum-containing medium was composed of Eagle's basal medium with Earle's salts, glutamine, glucose, penicillinstreptomycin, and $10 \%$ horse serum (Life Technologies).

Culture surfaces were pretreated overnight at $4^{\circ} \mathrm{C}$ with high molecular weight $(>300,000 \mathrm{kDa})$ poly-D-lysine $(500 \mu \mathrm{g} / \mathrm{ml}$; Sigma or Specialty Media) and washed three times with distilled water before use.

Mixed cerebellar cultures. Mixed cerebellar cultures were prepared as previously published (Baptista et al., 1994). Briefly, animals were killed by decapitation. Cerebella were dissected into calcium- and magnesiumfree PBS (CMF-PBS), and meninges were removed. Cerebella were digested with trypsin (1\% in CMF-PBS; Worthington, Freehold, NJ) for 3 min at room temperature. Trypsin was replaced with DNase $(0.05 \%$ in BME; Worthington), and cerebella were triturated with fire-polished Pasteur pipettes of three sequentially decreasing bore sizes. Cells were centrifuged and resuspended in CMF-PBS with DNase, and the cell slurry was passed through a $33 \mu \mathrm{M}$ nylon mesh filter. Cells were resuspended in horse serum medium, counted, diluted with serum-free medium, and plated at a density of $11 \times 10^{5}$ cells $/ \mathrm{cm}^{2}$ in Nunc Lab-Tek (Naperville, IL) $7 \mathrm{~mm}$ diameter wells $(300,000$ cells per well in $0.2 \mathrm{ml})$. This plating density produced a uniform monolayer.

Purkinje cell purification. Purkinje cells were purified essentially as previously described (Baptista et al., 1994) with some details changed. Briefly, cerebella were cut into three pieces and digested with papain (10 $\mathrm{U} / \mathrm{ml}$; Worthington) in a solution containing Earle's balanced salts $(1 \times$; Life Technologies), $\mathrm{NaHCO}_{3}(26 \mathrm{~mm})$, glucose $(0.5 \%)$, L-cysteine, and EDTA $(0.5 \mathrm{~mm})$ at $35.5^{\circ} \mathrm{C}$ for $45-60 \mathrm{~min}$. The papain solution was replaced with ovomucoid-(0.2\%; Boehringer Mannheim, Indianapolis, IN) or horse serum-containing medium, and tissue chunks were triturated sequentially with fire-polished Pasteur pipettes of three decreasing sizes to give a single-cell suspension. Cells were centrifuged and resuspended in ice-cold CMF-PBS containing DNase and then loaded onto cushions of $35 \%$ Percoll in CMF-PBS with EDTA. The cells accumulating at the $0-35 \%$ interface were removed and washed with CMF-PBS.

This cell fraction was resuspended in BME with $0.6 \%$ glucose and transferred onto anti-GD3 dishes prepared as follows. Four $6 \mathrm{~cm}$ Petri dishes (Falcon 1007) were coated the night before the purification at $4^{\circ} \mathrm{C}$ with goat anti-mouse IgG (Cappell-Worthington, Durham, NC; $20 \mu \mathrm{g} / \mathrm{ml}$ in $50 \mathrm{~mm}$ Tris $\mathrm{Cl}, \mathrm{pH} 9.5)$, washed with PBS the morning of the preparation, double-coated with anti-GD3 supernatant (HB8445, from the R24 hybridoma; American Type Culture Collection, Rockville, MD) at room temperature, washed again with $\mathrm{PBS}$, and preblocked with bovine serum albumin ( $2 \mathrm{mg} / \mathrm{ml}$; Sigma A-9418) in BME at $35.5^{\circ} \mathrm{C}$ for 1 hr. Glial cells were allowed to attach to the anti-GD3 dishes for $45 \mathrm{~min}$ at $35.5^{\circ} \mathrm{C}$, and nonadherent cells were transferred onto anti-Thy 1.2 dishes prepared as follows. Four $6 \mathrm{~cm}$ Petri dishes were coated the night before the purification at $4^{\circ} \mathrm{C}$ with anti-Thy 1.2 (Boeringer Mannheim $1199005 ; 2.7 \mu \mathrm{g} / \mathrm{ml}$ in $50 \mathrm{~mm}$ Tris $\mathrm{Cl}, \mathrm{pH} \mathrm{9.5),} \mathrm{washed} \mathrm{with} \mathrm{PBS,} \mathrm{and}$ preblocked with $\mathrm{BME}$ containing $\mathrm{BSA}$ at $35.5^{\circ} \mathrm{C}$ during the anti-GD3 panning step. Cells were allowed to attach to the anti-Thy 1.2 dishes for $45 \mathrm{~min}$ at $35.5^{\circ} \mathrm{C}$, and then nonadherent cells and debris were removed by seven to nine washes with warmed CMF-PBS. Adherent, highly enriched Purkinje cells were removed from the final panning plates with trypsinEDTA (0.05\%, $0.53 \mathrm{~mm}$; Life Technologies $25300-013)$ at $35.5^{\circ} \mathrm{C}$ for 10 min. The trypsin was inactivated by adding horse serum-containing medium, and the cells were centrifuged and resuspended in serum-free medium, counted, and plated at a density of 30,000 cells per Lab-Tek well (Nunc; this corresponds to $1 \times 10^{5}$ cells $/ \mathrm{cm}^{2}$ ). Cultures prepared in this way consisted of $85-95 \%$ calbindin-D $28 \mathrm{k}$-positive Purkinje cells, with $<5 \%$ GFAP-positive cells. When Purkinje cells and granule cells were cocultured, the granule cells were plated first in serum-free medium, and Purkinje cells were plated on top of the granule cells on the next day.

Granule cell purification. Cerebellar granule neurons were purified as previously described (Hatten, 1985; Baird et al., 1992). Briefly, cerebella were collected and digested as for the mixed cerebellar cultures (above), resuspended in CMF-PBS with DNase, and put through a two-step Percoll gradient. The dense cell fraction at the interface between the 35 and $60 \%$ Percoll phases was collected, and non-neuronal cells were removed by two sequential platings on Petri dishes precoated overnight with poly-D-lysine $(100 \mu \mathrm{g} / \mathrm{ml}$; Sigma) and washed as for the Lab-Tek wells. Nonadherent neuronal cells were collected, centrifuged at 1100 $\mathrm{rpm}$ for $5 \mathrm{~min}$, counted, and plated into poly-D-lysine-coated Lab-Tek wells at 300,000 cells per well (this corresponds to $11 \times 10^{5} \mathrm{cells} / \mathrm{cm}^{2}$ ). Cultures purified in this way consisted of $\sim 95 \%$ granule cells and typically contained $<5 \%$ GFAP-positive cells.

Growth factors, blocking antibodies, and glutamate receptor antagonists. Growth factors and TrkB-IgG were generously provided by Dr. G. Yancopoulos (Regeneron Pharmaceuticals, Tarrytown, NY). For each cerebellar cell combination, dose-response curves were generated for each growth factor. Subsequent experiments were designed to include concentrations of each growth factor that gave maximal Purkinje cell survival at 6 and 14 days in vitro (div). Optimal growth factor concentrations were as follows: NT-3, $50 \mathrm{ng} / \mathrm{ml} ; \mathrm{NT}-4,50 \mathrm{ng} / \mathrm{ml} ; \mathrm{BDNF}, 10$ $\mathrm{ng} / \mathrm{ml}$; and CNTF, $10 \mathrm{ng} / \mathrm{ml}$. TrkB-IgG was used at a final concentration of $25 \mu \mathrm{g} / \mathrm{ml}$.

Turkey polyclonal anti-BDNF antiserum (Ghosh et al., 1994) was obtained from Dr. J. Carnahan (Amgen, Thousand Oaks, CA) and used at a final dilution of 1:100.

The NMDA receptor antagonist D-APV and the non-NMDA receptor antagonist CNQX were purchased from Tocris Cookson and used at $50 \mu \mathrm{M}$.

Immunocytochemistry. Purkinje cells were visualized as previously published (Baptista et al., 1994) by immunostaining with a rabbit polyclonal antibody against calbindin- $\mathrm{D}_{28 \mathrm{k}}$ (Swant, Bellinzona, Switzerland). This marker has been shown to label Purkinje cells specifically within the cerebellum (Wassef et al., 1985; Christakos et al., 1987). In some experiments, glial cells were identified by immunostaining with a rabbit polyclonal antibody against glial fibrillary acidic protein generously supplied by Dr. R. Liem (Columbia University).

Cell cultures were fixed in $4 \%$ paraformaldehyde in $0.1 \mathrm{M}$ Sorensen's

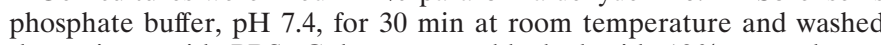
three times with PBS. Cultures were blocked with $10 \%$ normal goat serum in PBS containing $0.05 \%$ Triton X-100 for $30 \mathrm{~min}$. Cultures were incubated overnight at $4^{\circ} \mathrm{C}$ with primary antibody diluted 1:1000 in PBS containing $1 \%$ normal goat serum and $0.05 \%$ Triton X-100 and then washed three times with PBS. Cultures were incubated with goat antirabbit peroxidase- or rhodamine isothiocyanate-conjugated secondary antibody (Boehringer) diluted 1:100 in PBS containing 1\% goat serum and $0.05 \%$ Triton X-100 for $30 \mathrm{~min}$ at room temperature and washed three times with PBS. When Hoechst staining was desired, cultures were incubated for $10 \mathrm{~min}$ at room temperature in PBS containing $5 \mu \mathrm{g} / \mathrm{ml}$ Hoechst 33258 (Boehringer Mannheim) between the second and third washes. The peroxidase reaction was developed with $0.5 \mathrm{mg} / \mathrm{ml} \mathrm{diami-}$ nobenzidine (Wako Chemicals, Richmond, VA) and $0.006 \% \mathrm{H}_{2} \mathrm{O}_{2}$ in PBS. Cultures stained with peroxidase-conjugated secondary antibody were dehydrated through an ethanol series and mounted in Permount. Cultures stained with rhodamine-conjugated secondary antibody and Hoechst 33258 were mounted in GelMount (BioMeda) and photographed on a Zeiss AxioPhot.

Analysis of cultures. Purkinje cell survival was determined by counting all of the calbindin-positive cells in each Lab-Tek well using a Nikon Optiphot microscope with a $20 \times$ objective. The percentage of control cell survival for each treated well was determined by dividing the calbindin-positive cell count from that well by the cell count from its matched, untreated control well. All Purkinje cell survival estimates were made from at least two wells from each of at least three independent experiments, giving a total well number of at least six for each estimate. Calbindin-positive Purkinje cells were photographed using the $20 \times$ or $63 \times$ objectives on a Zeiss Axiophot with Nomarski optics.

Granule cell survival in Purkinje-granule cell cocultures was esti- 
mated by counting calbindin- $\mathrm{D}_{28 \mathrm{k}}$-negative granule cells with phase optics in eight randomly selected field positions using a Leitz Orthoplan microscope with a $63 \times$ objective and a camera lucida to mark the counted cells. This sample area contained 2000-3000 granule cells, representing $\sim 1.4 \%$ of the total Lab-Tek well surface. The percentage of control granule cell survival was calculated as described for Purkinje cell survival above. Granule cell survival data for glutamate antagonist and TrkB-IgG experiments were collected from at least two wells from each of at least three independent experiments, giving a total well number of at least six for each estimate. Granule cell survival data for anti-BDNF experiments represent five wells from a total of three independent experiments and four wells from two independent experiments, respectively.

Statistical analysis. Statistical comparisons were performed using the SAS software package or using Microsoft Excel paired $t$ tests. ANOVA was conducted using the SAS General Linear Models (GLM) procedure, which performs calculations similar to those of the ANOVA procedure but is preferable for data sets containing unequal sample sizes. For Figure 2, raw numbers of surviving Purkinje cells were compared with untreated, matched controls using GLM with Dunnett's $t$ tests. For Figure 3, Purkinje cell survival in growth factor-treated cultures was normalized to a percentage of survival in cultures with serum-free medium, and the differences in survival between serum-containing and serum-free conditions were compared within each growth factor treatment using paired $t$ tests. For Figures 4 and 5 , raw numbers were converted to a percentage of untreated control cell survival and then compared with survival in BDNF-treated cultures using GLM with Dunnett's $t$ tests.

\section{RESULTS}

\section{Effects of neurotrophins on Purkinje cell survival}

As a first approach to exploring the involvement of neurotrophins in Purkinje cell survival and development, we decided to study cerebellar cells in culture. This approach permits analysis of growth factor activities in a defined, serum-free medium, avoiding the confounding effects of additional growth factors present in serum. It also facilitates study of specific cell-cell interactions by allowing subsets of cells to be purified and selectively recombined. These advantages can help distinguish the direct effects of growth factors from those that are mediated indirectly, through other cell types, thus complementing in vivo approaches.

To determine the effects of neurotrophins on Purkinje cells in cultures containing defined cell populations, three cell combinations were studied: purified Purkinje cells cultured alone, purified Purkinje cells cocultured with purified granule cells, and mixed cultures from whole cerebella. Cerebellar granule neurons were purified and plated onto Nunc Lab-Tek wells at a density of 300,000 cells per well $\left(\sim 11 \times 10^{5}\right.$ cells $\left./ \mathrm{cm}^{2}\right)$. Purkinje cells were purified and plated at 30,000 cells per well. Mixed cultures were prepared by dissociating whole cerebella and plating 300,000 cells per well. All cultures were grown in serum-free medium unless otherwise indicated. Plated cells were allowed to attach to the culture substrate for 60-90 min, and then the medium was changed to medium including growth factors, neurotrophinblocking reagents, or glutamate receptor antagonists. After the day of plating, the medium was changed every 3-4 d, and each medium change included fresh growth factors or blocking reagents.

Purkinje cell development in cultures of dissociated whole cerebellum or in cocultures of purified Purkinje and granule neurons mimics development in vivo. At E17-P2 in vivo or 7 div, Purkinje cells have numerous short perisomatic processes. By postnatal day 7 in vivo or 14 div, apical dendrites emerge, bearing spines that receive synapses from granule cell parallel fibers (Fig. $1 C, E)$. By $\mathrm{P} 10$-adult in vivo or 21 div, higher-order dendrite branching and high-density spines with synapses are well estab- lished (Weber and Schachner, 1984; Hockberger et al., 1989; Armengol and Sotelo, 1991; Schilling et al., 1991; Baptista et al., 1994). We chose to examine Purkinje cell survival and development at 6 div, during initial dendrite development, and 14 div, a time when Purkinje cell dendrites are maturing and receiving granule cell synapses. Cultures were fixed with $4 \%$ paraformaldehyde at 6 or 14 div and immunostained with an antibody against calbindin- $\mathrm{D}_{28 \mathrm{k}}$, a marker found throughout the brain but specific within the cerebellum for Purkinje cells (Wassef et al., 1985; Christakos et al., 1987).

Purkinje cell survival is profoundly affected by cell context. Purkinje cells cultured alone, with no growth factor treatment, yield relatively fewer surviving cells than Purkinje cells cocultured with granule cells or in mixed cerebellar cultures (Baptista et al., 1994) (Table 1). To facilitate comparison of growth factor effects among different cell combinations, normalization to survival in control cultures is necessary. Purkinje cell survival in treated cultures is therefore expressed as a percentage of survival in matched, untreated control cultures having the same cell combination at the same time point.

Trophic factor modulation of Purkinje cell survival was examined using three different cell combinations: Purkinje cells alone, Purkinje cells cocultured with granule neurons, and mixed cerebellar cells. Cultures were treated with each of four growth factors: NT-3, NT-4, BDNF, and CNTF. The concentration of growth factors used was determined by generating dose-response curves for each cell combination with each growth factor at concentrations ranging from 0.1 to $1000 \mathrm{ng} / \mathrm{ml}$ (data not shown). For Purkinje cells cultured alone, $50 \mathrm{ng} / \mathrm{ml} \mathrm{NT}-4$ or $10 \mathrm{ng} / \mathrm{ml}$ BDNF gave optimal increases in survival relative to those in untreated control cultures at $14 \mathrm{div}$ (Fig. 2A). In contrast, 50 $\mathrm{ng} / \mathrm{ml} \mathrm{NT}-3$ or $10 \mathrm{ng} / \mathrm{ml} \mathrm{CNTF}$ decreased Purkinje cell survival at 6 or $14 \mathrm{div}$ (Fig. 2A). No higher or lower growth factor concentrations from the dose-response experiments gave greater Purkinje cell survival for any of the three cell combinations. All subsequent experiments were therefore conducted using these concentrations of growth factors.

BDNF or NT-4 increased survival of Purkinje cells cultured alone (Fig. 2A). When Purkinje cells were cocultured with granule neurons, their normal presynaptic afferents (Fig. $2 B$ ), or when Purkinje cells were cultured in the presence of mixed cerebellar cells (Fig. 2C), the survival-enhancing effects of NT-4 or BDNF apparent in Purkinje cells cultured alone were counteracted. Although NT-4 in cultures of Purkinje cells alone at 14 div gave $148 \%$ of untreated control cell survival, NT-4 in Purkinje-granule cocultures gave only $13 \%$ of control cell survival, and NT-4 in mixed cultures gave $29 \%$ of control cell survival (Fig. 2). Although BDNF in cultures of Purkinje cells alone at 14 div produced $147 \%$ of control cell survival, addition of BDNF when granule cells were present reduced Purkinje cell survival to $24 \%$ of control levels, and BDNF treatment of mixed cultures reduced Purkinje cell survival to $33 \%$ of control levels. NT-3 or CNTF treatment decreased Purkinje cell survival in all cell combinations tested (Fig. 2). All combinations of these four growth factors were also tested, but no combination increased Purkinje cell survival above that in the singly treated cultures (data not shown).

In summary, although BDNF or NT-4 increased the survival of purified Purkinje cells cultured alone, addition of exogenous neurotrophins when Purkinje and granule cells were both present resulted in Purkinje cell death. 

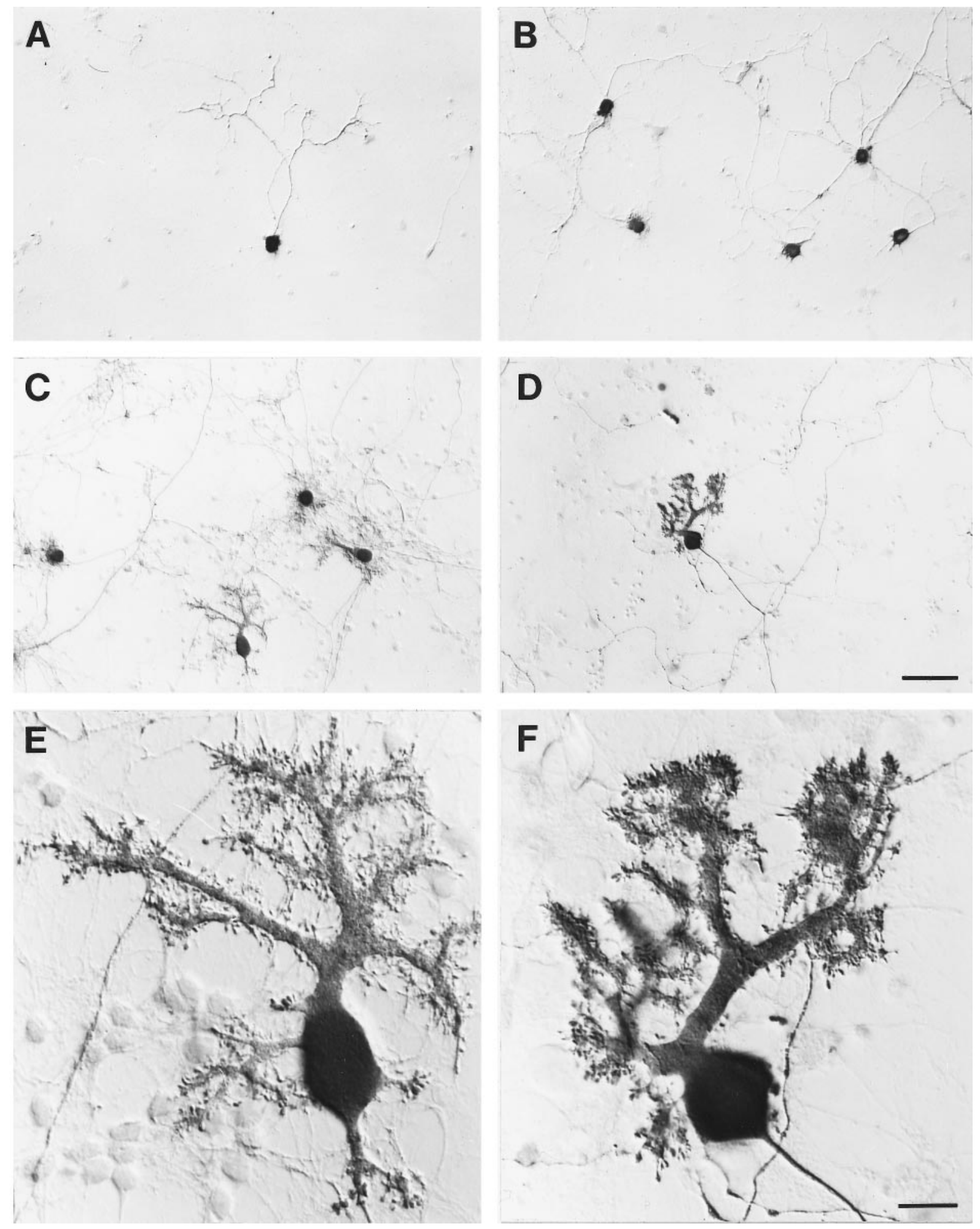

Figure 1. Purkinje cell development with and without granule cell afferents and BDNF. $A$, $B$, Purkinje cells cultured alone; $C-F$, Purkinje cells cocultured with granule cells; $A, C, E$, no BDNF added; $B, D, F$, with BDNF. All cultures were fixed at 14 div and immunostained with anti-calbindin ${ }_{\mathrm{D} 2 \mathrm{Bk}}$ peroxidase. Scale bars: $A-D, 50 \mu \mathrm{m} ; E, F, 10 \mu \mathrm{m}$.

\section{BDNF and Purkinje cell dendritic differentiation}

Purified Purkinje cells cultured alone extend axons but develop only rudimentary, unbranched dendrites resembling the "perisomatic process" stage of Purkinje cells in vivo (Baptista et al., 1994) (Fig. 1A). Purified Purkinje cells cultured with granule neurons elaborate axons and mature, highly branched dendrites bearing spines (Baptista et al., 1994) (Fig. 1C). Despite the increase in purified Purkinje cell survival with BDNF or NT-4 treatment (Fig. 2A), none of the growth factors tested triggered development of mature dendrites in cultures containing only purified 
Table 1. Cell context affects Purkinje cell survival

\begin{tabular}{|c|c|c|c|}
\hline \multirow[b]{2}{*}{ Culture type } & \multirow{2}{*}{$\begin{array}{l}\text { Cell number } \\
\text { at initial plating }\end{array}$} & \multicolumn{2}{|c|}{ Purkinje cells per well ${ }^{a}$} \\
\hline & & $6 \operatorname{div}^{b}$ & $14 \mathrm{div}$ \\
\hline Purkinje cells alone & 30,000 & $619 \pm 115(n=12)$ & $271 \pm 63(n=10)$ \\
\hline \multicolumn{4}{|l|}{ Purkinje + granule cells } \\
\hline Purkinje cells & 30,000 & $1453 \pm 205(n=11)$ & $1327 \pm 194(n=13)$ \\
\hline Granule cells & 300,000 & & \\
\hline \multirow{2}{*}{$\begin{array}{l}\text { Mixed cerebellar cells } \\
\text { (contains approximately } \\
15,000 \text { Purkinje cells at } \\
\text { time of plating) }\end{array}$} & & & \\
\hline & 300,000 & $597 \pm 78(n=11)$ & $371 \pm 48(n=12)$ \\
\hline
\end{tabular}

${ }^{a}$ Numbers indicate mean $\pm \mathrm{SE}$.

${ }^{b}$ div, Days in vitro.

Purkinje cells (Fig. 1B) (data not shown). In neurotrophintreated cocultures containing Purkinje and granule cells, Purkinje cell survival was reduced relative to untreated controls, but the Purkinje cells that did survive developed dendrites with branch orders similar to those in untreated control cultures (Fig. $1 C-F$ ). BDNF treatment of cocultures seemed to increase spine density (Fig. $1 E, F$ ). These results will be detailed in a separate report. Combined with recent data on Purkinje cell development in $B D N F^{-1-}$ mice (Schwartz et al., 1997), these effects on spine density imply that BDNF may be required for at least two stages of Purkinje cell dendrite development (see Discussion).

\section{Serum alters responses to growth factor treatment in mixed cultures}

BDNF or NT-4 increases survival of purified Purkinje cells cultured alone, and NT-3 or CNTF decreases survival of purified Purkinje cells whether they are cultured alone or with granule cells. These results are in marked contrast to previous studies that showed that BDNF decreases (Mount et al., 1993), CNTF increases (Larkfors et al., 1994, 1996), and NT-3 either boosts (Mount et al., 1994) or has no effect on (Lindholm et al., 1993) Purkinje cell survival. Several factors could account for the differences between the experiments presented here and those from other laboratories. The first difference is that all of the latter studies used cultures of mixed cerebellar neurons and glia, rather than purified cells. The second difference is that others frequently used serum-containing medium, rather than the serum-free medium used here. The third difference is that others used animals of ages different from those used here. To determine the source of the differences between our results and those published previously, we compared the effects of neurotrophins on matched mixed cerebellar cultures, from animals of different ages, using serum-containing or serum-free media.

Under control conditions with no growth factor treatment in mixed cultures from P0 cerebella, more Purkinje cells survive in serum-free medium than in horse serum-containing medium (Fig. $3 ; p<0.05)$. This trend is reversed when serum and neurotrophins are present together; a higher percentage of Purkinje cells survive relative to controls in neurotrophin-treated cultures with serum-containing medium than with serum-free medium (Fig. 3). Only CNTF treatment gave better Purkinje cell survival with serum-free medium than with serum. It therefore seems likely that serum affects neurotrophin effects on Purkinje cell survival, explaining part of the difference between our results and previous reports.

Another difference between our experiments and those from other laboratories is the age of the animals used to prepare cultures. The present experiments studied Purkinje cells purified from perinatal mice, whereas other laboratories have used mixed cultures of cerebellar cells from E16 rats. Experiments comparing neurotrophin effects on purified cells from animals of different ages were not possible in the present study, because the Purkinje cell purification protocol in its present form requires perinatal animals. Surface levels of GD3 and Thy 1.2, the cell surface markers used for the immunopanning steps in the purification procedure, are optimal at perinatal ages. Comparison of mixed cerebellar cultures from P0 and E14 mice, however, revealed no age-related differences in the deleterious effects of NT-3, NT-4, or BDNF on Purkinje cell survival under serum-free conditions (data not shown). More Purkinje cells in CNTF-treated mixed cultures survived when the cultures were prepared from E14 rather than $\mathrm{P} 0$ mice, although we did not observe an increase in Purkinje cell survival over $100 \%$ of untreated control levels with CNTF treatment, as had been previously reported.

Taken together, these results implicate serum in altering the response of Purkinje cells to neurotrophin treatment. Although inclusion of serum does not explain all of the previously mentioned quantitative differences in Purkinje cell survival, other uncontrolled factors, such as different degrees of glial contamination in previous reports, may also account for some differences between our results and those of others.

\section{BDNF-blocking reagents counteract BDNF-induced toxicity of Purkinje cells cocultured with granule cells}

The expression patterns of neurotrophins and their receptors within the cerebellum suggest a mechanism for neurotrophininduced Purkinje cell loss when Purkinje cells are cocultured with their granule cell afferents. Granule cells express BDNF RNA (Hofer et al., 1990; Lindholm et al., 1993; Rocamora et al., 1993) and TrkB receptors (Gao et al., 1995; Segal et al., 1995). Purkinje cells, the postsynaptic target of granule cells, do not express RNA encoding BDNF (Hofer et al., 1990; Rocamora et al., 1993) but do contain BDNF protein (Dugich-Djordjevic et al., 1995) and TrkB receptors (Gao et al., 1995). Granule cells may therefore normally produce BDNF that is transferred to Purkinje cells, enhancing Purkinje cell survival. Our finding that BDNF increases survival of Purkinje cells cultured alone to $147 \%$ of the control level (Fig. 2A), combined with previous findings that granule cells increase survival of Purkinje cells (Baptista et al., 1994), supports this hypothesis. Under this model, the BDNFinduced decrease in Purkinje cell survival (toxicity) in Purkinje cell-granule neuron cocultures could be attributable to excess, 

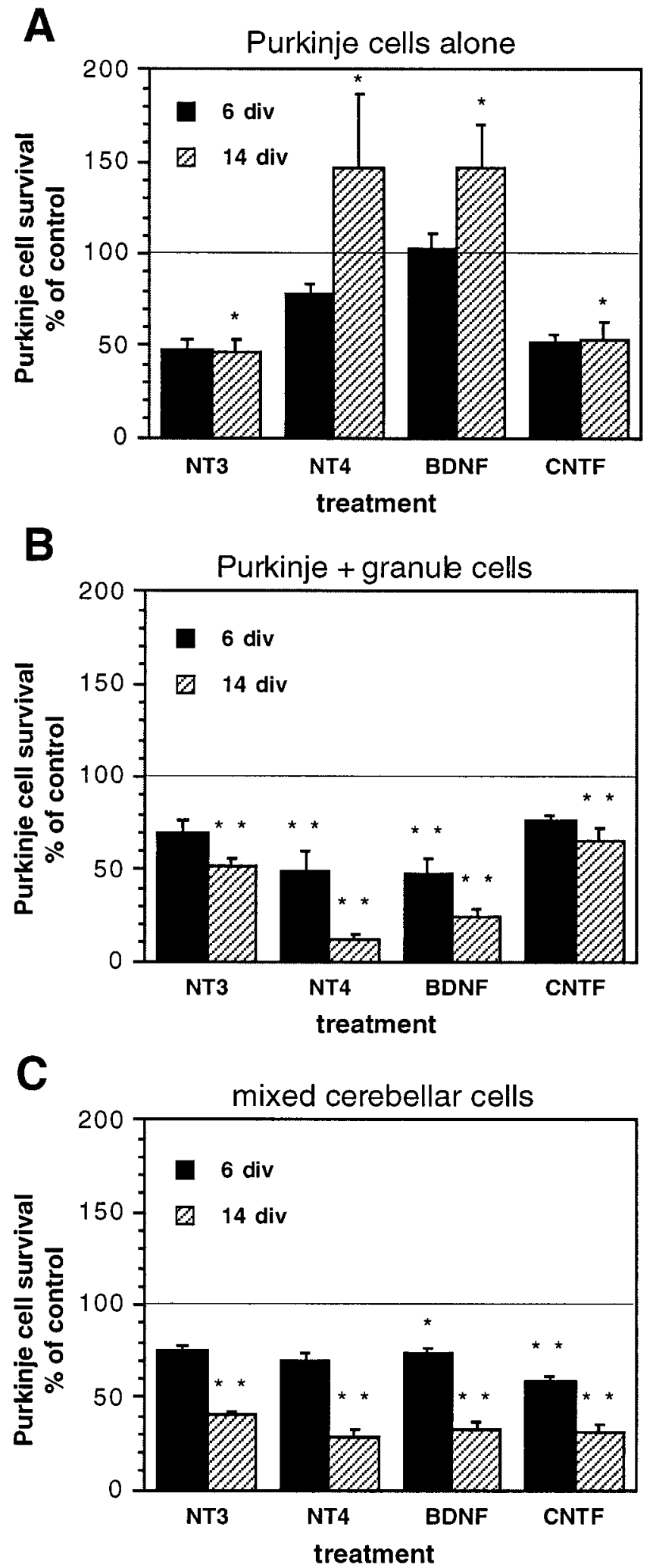

Figure 2. Cell context alters trophic factor modulation of Purkinje cell survival. $A$, Purkinje cells cultured alone; $B$, Purkinje cells cocultured with granule cells; $C$, mixed cultures of whole cerebellum. Purkinje cell survival is represented as a percentage of the Purkinje cell number in untreated, matched control cultures at each time point. Error bars indicate SE. div, Days in vitro. Line, $100 \%$ of control cell survival. Asterisks, Statistically significant differences from untreated control cell survival; ${ }^{*} p<0.05 ; * * p<0.01$.

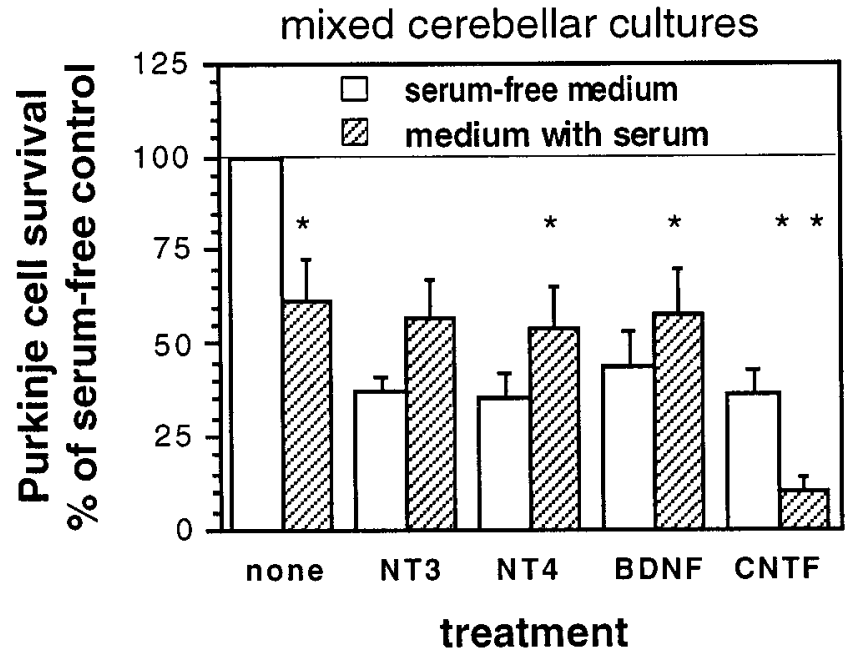

Figure 3. Serum alters responses to growth factor treatment in mixed cultures. Purkinje cell survival is represented as a percentage of Purkinje cell number in untreated cultures with serum-free medium. Fewer untreated Purkinje cells survive in horse serum than in serum-free medium, but this trend is reversed when serum and neurotrophins are present together. Mixed cerebellar cells from perinatal mice were cultured in serum-free medium or in medium containing $10 \%$ horse serum for 14 div. Error bars indicate SE. Asterisks, Significant differences between serumfree and serum-containing conditions; ${ }^{*} p<0.05 ;{ }^{* *} p<0.01$.

exogenous BDNF beyond the levels of BDNF normally supplied to Purkinje cells by the granule neurons.

To test the hypothesis that BDNF in excess of that provided by granule cells becomes toxic to Purkinje cells in granule-Purkinje cell cocultures, either TrkB-IgG fusion protein or anti-BDNF antiserum previously shown to block BDNF signaling (Ghosh et al., 1994) was added to the culture medium. As in the experiments shown in Figure 2, BDNF treatment decreased the survival of cocultured Purkinje cells relative to that of untreated controls (Fig. 4). TrkB-IgG fusion protein was more efficient than antiBDNF at rescuing Purkinje cells from BDNF-induced death (Fig. 4). At 6 div, TrkB-IgG increased Purkinje cell survival in BDNFtreated cocultures from 31 to $89 \%$ of control survival $(p<0.01)$. At 14 div, TrkB-IgG increased Purkinje cell survival from 17 (BDNF-only) to $98 \%$ (BDNF plus TrkB-IgG) of control survival $(p<0.01)$. TrkB-IgG alone had little or no effect on Purkinje cell survival (Fig. 4A). Possible explanations for this result are explored in Discussion.

Inclusion of anti-BDNF in the medium of cultures treated with BDNF produced a partial rescue from BDNF-induced Purkinje cell death. This rescue was specific, because treatment of Purkinjegranule cocultures (or of Purkinje cells cultured alone) with anti-BDNF alone did not alter Purkinje cell survival relative to that in untreated control cultures (Fig. 4B) (data not shown). At 6 div, treatment with BDNF gave $56 \%$ of control cell survival, whereas treatment with BDNF and antibody gave $80 \%$ of control cell survival (Fig. $4 B$ ). At 14 div, BDNF treatment gave $25 \%$ of control cell survival, whereas addition of BDNF and antibody gave $54 \%$ of control cell survival, double that in cultures treated with BDNF alone (Fig. 4B).

These results are consistent with the hypothesis that BDNF in excess of that normally supplied by the granule cells is toxic to Purkinje cells. 
A

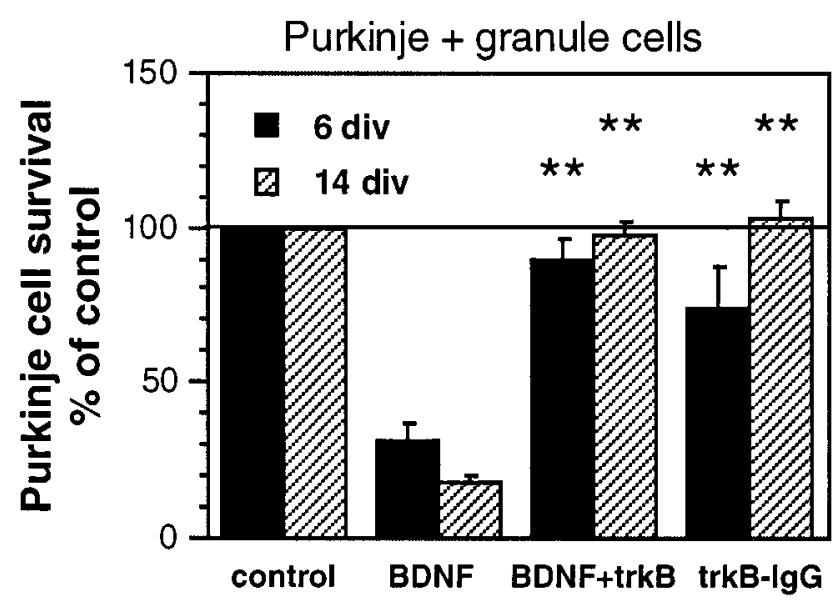

treatment

B

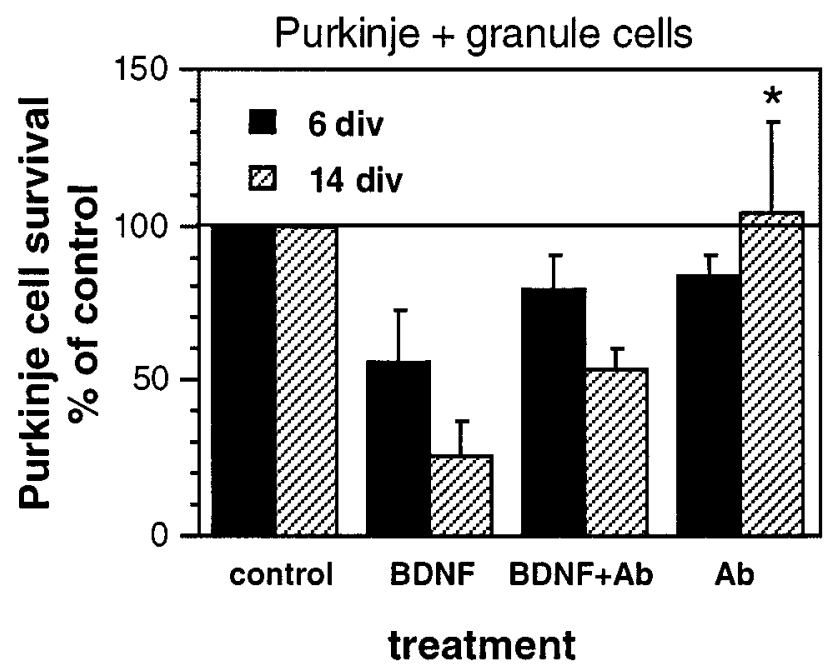

Figure 4. Reagents that block BDNF signaling block BDNF-induced toxicity of Purkinje cells cocultured with granule cells. $A$, TrkB-IgG fusion protein experiments; $B$, anti-BDNF antiserum experiments. Purified Purkinje and granule cells were cultured in serum-free medium for 6 or 14 div, with or without $10 \mathrm{ng} / \mathrm{ml}$ BDNF, TrkB-IgG fusion protein (final concentration, $25 \mu \mathrm{g} / \mathrm{ml}$ ), or turkey anti-BDNF antiserum (final dilution, 1:100). Purkinje cell survival is represented as a percentage of the Purkinje cell number in matched control cultures at each time point. Error bars indicate SE. div, Days in vitro; $A b$, anti-BDNF. Asterisks, Statistically significant differences from BDNF-treated cultures; ${ }^{*} p<0.05 ;{ }^{* *} p<0.01$.

\section{CNQX, but not APV, rescues cocultured Purkinje cells from BDNF toxicity}

BDNF (or other neurotrophins) increases synaptic transmission in hippocampal slices and in the neuromuscular junction (Kang and Schuman, 1995; Stoop and Poo, 1996). We therefore hypothesized that if the glutamatergic granule cells release glutamate in response to BDNF treatment, decreased survival of Purkinje cells cocultured with granule cells and treated with BDNF might be caused by glutamate-induced excitotoxicity. In support of this idea, dose-response curves revealed that glutamate added to cultures of purified Purkinje cells decreased their survival, even at concentrations as low as $3 \mu \mathrm{M}$ (data not shown). Glutamate
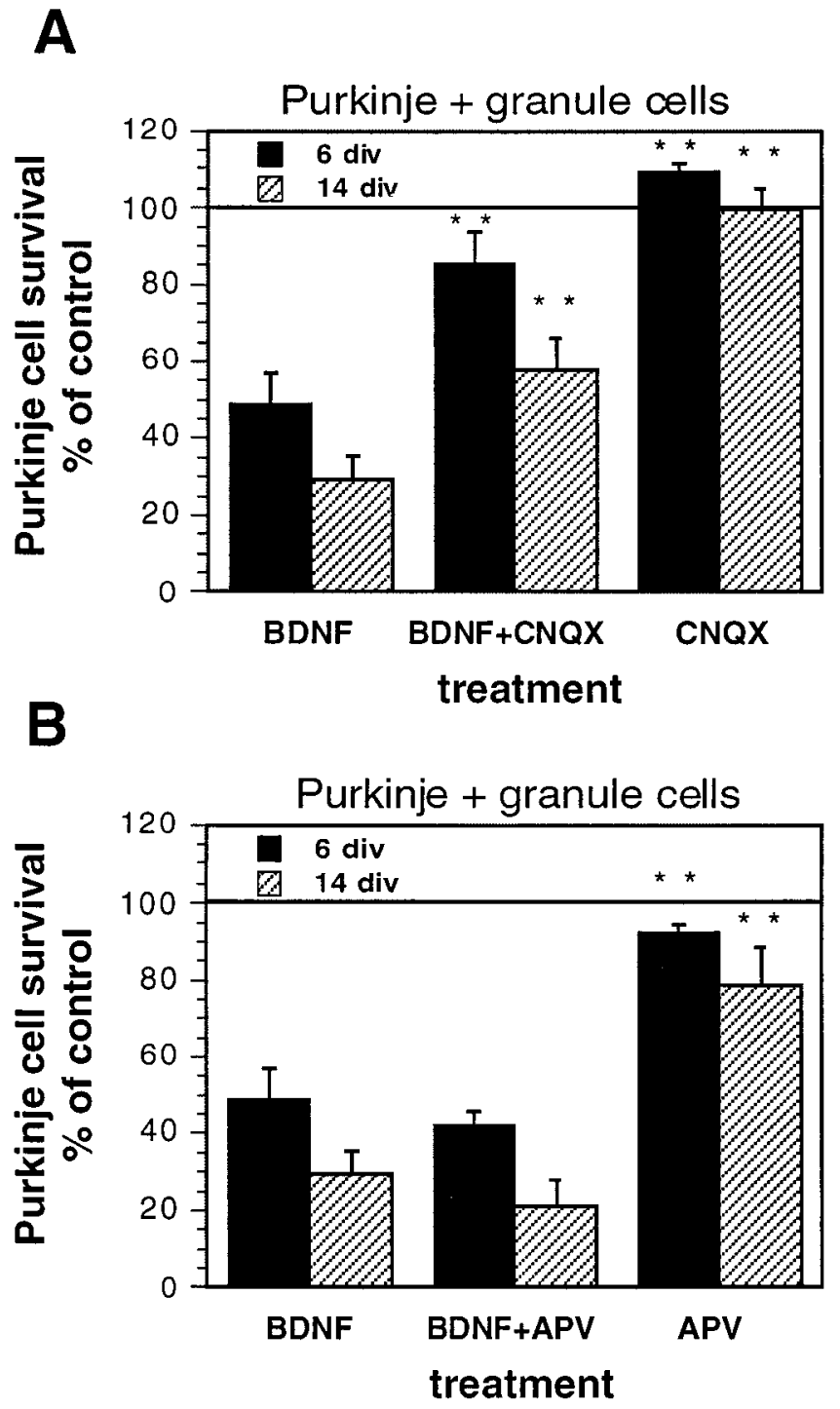

Figure 5. CNQX, but not APV, rescues Purkinje cells from BDNF toxicity. $A$, Experiments with CNQX; $B$, experiments with APV. Purified Purkinje and granule cells were cocultured in serum-free medium for 6 or 14 div, with or without $10 \mathrm{ng} / \mathrm{ml} \mathrm{BDNF}, 50 \mu \mathrm{M}$ APV (an NMDA receptor antagonist), or $50 \mu \mathrm{M}$ CNQX (a non-NMDA receptor antagonist). Purkinje cell survival is represented as a percentage of the Purkinje cell number in untreated control cultures at each time point. Error bars indicate SE. div, Days in vitro. Asterisks, Statistically significant differences from BDNF-treated cultures; ${ }^{* *} p,<0.01$.

receptor antagonists were used in an attempt to block BDNFinduced toxicity in granule cell-Purkinje cell cocultures treated with BDNF. The non-NMDA receptor-specific antagonist CNQX partially rescued Purkinje cell survival in BDNF-treated cocultures with granule cells (Fig. $5 A ; p<0.01$ at 6 or 14 div), whereas the NMDA receptor-specific antagonist APV failed to rescue cocultured Purkinje cells treated with BDNF (Fig. 5B). Neither antagonist alone changed the percentage of Purkinje cell survival in cocultures without BDNF (Fig. 5A,B). These results support the growing literature describing non-NMDA receptormediated forms of excitotoxicity (Tokita et al., 1996; Pozas et al., 1997), implicating non-NMDA receptor-mediated glutamate excitotoxicity as a mechanism of BDNF-induced cell death in cocultures of Purkinje and granule cells. 


\begin{tabular}{|c|c|c|}
\hline Treatment & $\begin{array}{l}\text { Purkinje cells } \\
\text { (\% of control) }\end{array}$ & $\begin{array}{l}\text { Granule cells } \\
\text { (\% of control) }\end{array}$ \\
\hline Control & 100 & 100 \\
\hline BDNF alone $\mathrm{e}^{a, b, c}$ & $26 \pm 4$ & $66 \pm 3^{d}$ \\
\hline $\mathrm{BDNF}+\operatorname{TrkB}-\operatorname{IgG}^{a}$ & $89 \pm 6$ & $120 \pm 7^{e}$ \\
\hline TrkB-IgG alone ${ }^{a}$ & $94 \pm 7$ & $126 \pm 6$ \\
\hline $\mathrm{BDNF}^{+}$anti-BDNF${ }^{b}$ & $54 \pm 7$ & $49 \pm 7^{f}$ \\
\hline anti-BDNF alone $e^{b}$ & $105 \pm 29$ & $52 \pm 7$ \\
\hline $\mathrm{BDNF}+\mathrm{CNQX}^{c}$ & $58 \pm 8$ & $77 \pm 4^{g}$ \\
\hline CNQX alone ${ }^{c}$ & $100 \pm 5$ & $95 \pm 5$ \\
\hline
\end{tabular}

Purkinje and granule cell survival at 14 div is given as a percentage of control cell survival (average $\pm \mathrm{SE}$ ).

${ }^{a}$ Data from experiments in Figure $4 A$.

${ }^{b}$ Data from experiments in Figure $4 B$.

${ }^{c}$ Data from experiments in Figure $5 A$.

${ }^{d}$ With BDNF treatment, Purkinje cell loss exceeds granule cell loss.

${ }^{e}$ TrkB-IgG increases BDNF-treated Purkinje cell survival while increasing granule cell survival.

${ }^{f}$ Anti-BDNF increases BDNF-treated Purkinje cell survival despite decreasing granule cell survival.

${ }^{g}$ CNQX increases BDNF-treated Purkinje cell survival without restoring granule cell survival to control levels.

\section{BDNF-induced Purkinje cell loss is not explained by decreased granule cell number}

Granule cell number can influence Purkinje cell survival in cocultures (Baptista et al., 1994). To test whether the Purkinje cell loss in BDNF-treated cocultures was secondary to decreases in granule cell number, we counted granule cells in cocultures used for the anti-BDNF, TrkB-IgG, or CNQX experiments presented in Figures 4 and 5 (Table 2). At 14 div, BDNF treatment reduced granule cell survival to $66 \pm 3 \%$ of control levels, compared with Purkinje cell survival at $26 \pm 4 \%$ of control levels (Table 2). At 6 div, BDNF treatment decreased the number of granule cells to $74 \pm 10 \%$ of control granule cell survival levels, compared with Purkinje cell survival at $51 \pm 8 \%$ of control levels (data not shown). Previous work from this laboratory established that reducing granule cell number to $72 \%$ of control granule cell levels produced Purkinje cell survival at $93 \%$ of control Purkinje cell levels (Baptista et al., 1994). Thus, the granule cell numbers present in our BDNF-treated cultures are sufficient to support full Purkinje cell survival. Moreover, Purkinje cell survival may be increased independent of granule cell numbers. TrkB-IgG treatment restores Purkinje cell survival in BDNF-treated cocultures and increases granule cell number, but CNQX treatment improves Purkinje cell survival without significant changes in granule cell number. Anti-BDNF treatment increases Purkinje cell survival in BDNF-treated cocultures despite decreasing the number of granule cells (Table 2). We therefore conclude that the large reductions in Purkinje cell survival seen in BDNF-treated cocultures are not explained by granule cell loss.

\section{DISCUSSION}

A plethora of protein and mRNA localization studies have suggested that neurotrophins function during cerebellar cell maturation, providing the impetus for testing the role of growth factors in cerebellar cultures (Lindholm et al., 1993; Mount et al., 1993; Larkfors et al., 1994, 1996). We have extended these early experiments, examining neurotrophin influences on Purkinje cell survival and dendrite development using purified Purkinje cells and purified granule cell afferents.

\section{Neurotrophin effects on Purkinje cell survival vary depending on cell-cell interactions}

Cerebellar granule cells contain BDNF RNA (Hofer et al., 1990; Lindholm et al., 1993; Rocamora et al., 1993). Purkinje cells do not express RNAs encoding BDNF or NT3 (Hofer et al., 1990; Lindholm et al., 1993; Rocamora et al., 1993) but do contain BDNF and NT3 proteins in vivo (Zhou and Rush, 1994; DugichDjordjevic et al., 1995). Both granule and Purkinje cells display TrkB protein on their surfaces (Gao et al., 1995; Segal et al., 1995; Lindholm et al., 1997).

Based on these expression data and on the fact that granule cells are presynaptic to Purkinje cells, we predicted that BDNF signaling would occur in granule-Purkinje cell cocultures and that exogenous BDNF would affect Purkinje cell survival and/or differentiation. Consistent with these predictions, BDNF increased the survival of Purkinje cells cultured alone (Fig. $2 A$ ). In contrast, BDNF added to granule cell-Purkinje cell cocultures decreased Purkinje cell survival (Fig. 2B) beyond levels that might be explained by concomitant loss of granule cells (Table 2), implicating the cellular environment (absence or presence of granule cells) and corresponding levels of BDNF and TrkB expression in determining whether BDNF treatment promotes survival or death of Purkinje cells.

The results presented here differ significantly from those already in the literature. Specifically, CNTF was reported to increase Purkinje cell survival above untreated controls in mixed cultures from E16 rats (Larkfors et al., 1994, 1996) but decreased Purkinje cell survival under our culture conditions (Fig. 2). BDNF, previously shown to decrease Purkinje cell survival (Mount et al., 1993), actually increased survival of purified Purkinje cells cultured alone (Fig. $2 A$ ). Comparison of our methods with those used previously revealed several differences that may account for our novel results. Principal among these is use of serum-containing medium, which alters the effects of all the growth factors tested here on Purkinje cells (Fig. 3). Our study included purified cell populations in addition to a mixture of cerebellar cells, and our results highlight the importance of using defined cell populations in unraveling which factors directly contribute to Purkinje cell survival and differentiation.

\section{Neurotrophins can mediate cell death}

A new view of neurotrophin action is emerging, including the concept that in addition to their growth- and differentiationenhancing effects, neurotrophins can induce neuronal death if introduced at improper levels or times, either through their Trk receptors or p75, and associated neurotransmitter receptors (NGF, von Bartheld et al., 1994; Cassaccia-Bonnefil et al., 1996; Frade et al., 1996; BDNF or NT-3, Fernandez-Sanchez and Novelli, 1993, 1995; Koh et al., 1995). Such analyses led Koh et al. (1995) to propose that although neurotrophins function to protect neurons from apoptosis, they also may potentiate neuronal death by necrosis (Koh et al., 1995). Results from Hoechst 33258 staining of granule-Purkinje cell cocultures support this idea. All Purkinje cells in cocultures with granule cells at 6 or 14 div contain nuclei diffusely labeled by Hoechst staining, suggesting that any Purkinje cell death occurring at these times is necrotic (data not shown). These data indicate that a precise balance between BDNF signaling and glutamate stimulation is vital for Purkinje cell survival, with excess BDNF triggering Purkinje cell death.

The finding that cellular environment and/or contacts can alter Purkinje cell responses to growth factors has implications for 
experiments involving growth factor administration to the intact nervous system (Cabelli et al., 1995; Riddle et al., 1995). In such experiments, the reagents may exert their effects indirectly, by damaging bystander cells, as well as directly, by stimulating target cells. These results suggest that general application of neurotrophins in vivo may upset critical balances and lead to unintended neuronal loss.

\section{A model for Purkinje cell-granule neuron interactions}

A model for Purkinje and granule cell interactions that hinges on a balance between glutamate stimulation and neurotrophin signaling illuminates the effects of neurotrophins and glutamate receptor antagonists on Purkinje cell survival. Purkinje cells cultured alone survive poorly, developing axons but not dendrites (Fig. 1A). Addition of BDNF increases survival of isolated Purkinje cells but does not drive dendritic differentiation (Fig. 1B). Granule cells cultured with Purkinje cells enhance Purkinje cell survival and induce dendrite formation, most likely through a combination of glutamate stimulation and BDNF production by the glutamatergic granule cells (Fig. 1C). Adding exogenous BDNF to such Purkinje-granule cocultures may stimulate the granule cells to produce even more glutamate, which in turn becomes excitotoxic to the Purkinje cells. In support of this hypothesis, glutamate added continuously to Purkinje cells cultured alone was toxic at concentrations as low as $3 \mu \mathrm{M}$ (data not shown). Decreasing the BDNF overload with anti-BDNF antibodies or with TrkB-IgG brings the system back toward the proper balance of BDNF and glutamate action, restoring Purkinje cell survival (Fig. 4). Purkinje cells in cocultures with granule cells also can be protected from BDNF-induced death by CNQX, a specific non-NMDA glutamate receptor antagonist (Fig. 5), supporting the hypothesis that Purkinje cell loss in BDNF-treated cocultures is attributable in part to glutamate excitotoxicity. This hypothesis provides one possible explanation for the lack of effects of anti-BDNF or TrkB-IgG alone on Purkinje cell survival in cocultures (Fig. 4). Anti-BDNF or TrkB-IgG may reduce the activity of the granule cells, reducing ill effects on Purkinje cells from overstimulation by granule cells, thus boosting survival and counteracting the expected reduction in Purkinje cell survival predicted from simple BDNF deprivation.

Alternatively, if excitation of granule cell-Purkinje cell synapses causes an increase in Purkinje cell TrkB levels, the BDNFinduced Purkinje cell death in cocultures may be attributable to increased sensitivity of the Purkinje cells to BDNF itself and not to glutamate excitotoxicity. In this case, CNQX may rescue Purkinje cells in BDNF-treated cocultures by blocking the glutamate signaling that would normally increase TrkB expression in Purkinje cells, rather than by blocking direct glutamate excitotoxicity. This alternate model would require that the Purkinje cell distinguish between two signaling conditions, responding to changes in BDNF signaling caused by increased exogenous BDNF with increased survival versus responding to changes in BDNF signaling caused by increased TrkB receptor levels with decreased survival. Electrophysiological recordings and measurements of levels of TrkB in cultures with and without BDNF and CNQX treatment would clarify which of these two models is correct.

\section{The role of BDNF in cerebellar development}

A growth factor such as BDNF with survival effects on Purkinje cells might be expected to induce their dendritic differentiation. A precedent for single-factor induction of de novo dendrite forma- tion is OP-1, a member of the BMP/TGF $\beta$ family that has striking effects on dendrite outgrowth of sympathetic neurons (Lein et al., 1995). Indeed, NT-3 was previously reported to increase neurite outgrowth of Purkinje cells in mixed cerebellar cultures (Lindholm et al., 1993). Although BDNF and NT4 increased the survival of Purkinje cells cultured alone (Fig. 2A), none of the neurotrophins tested here was able to induce Purkinje dendrite formation de novo, in the absence of granule cells. These results are consistent with the idea that CNS neurons in general may require a menu of signals for their survival and dendritogenesis (Meyer-Franke et al., 1995).

Our results provide an interesting counterpoint to those of Segal et al. (1995), who recently reported increased granule cell death and stunting of Purkinje cell dendrites in $B D N F^{-1-}$ mice (Schwartz et al., 1997). All of the cells in these mice developed from their genesis in an environment lacking BDNF. Schwartz et al. (1997) concluded that BDNF acts to influence dendritic morphology but is not required for granule cell-Purkinje cell synapse formation. In our experimental paradigm, granule and Purkinje cells are generated and begin to develop in the presence of normal BDNF levels but are deprived of BDNF by antibody or TrkB-IgG treatment later on, during a 2 week culture period. Preliminary evidence indicates that this late deprivation of BDNF does not alter dendritic branch structure, whereas late addition of BDNF increases spine density (Fig. 1). Combined with the results of Schwartz et al. (1997), these observations suggest that normal Purkinje cell development requires BDNF or TrkB activity during at least two distinct phases: prenatally, for effects on future branch structure, and postnatally, for effects on spine density.

BDNF effects on spine density would support the idea that neurotrophins may act on later stages of dendrite development, including higher-order branching and spine formation (McAllister et al., 1995, 1996, 1997), as well as on axonal outgrowth (Ghosh et al., 1994; Cohen-Cory and Fraser, 1995; Cohen-Cory et al., 1996; Sawai et al., 1996). This is consistent with the synaptotrophic hypothesis that neurotrophins exert their effect on neuronal growth, differentiation, and plasticity by mediating synaptic competition (Snider and Lichtman, 1996). One of the predictions of this hypothesis is that neurotrophins are released in a restricted manner, possibly at synaptic contacts. Such a mechanism is implicated by recent findings revealing a role for BDNF in synaptic plasticity (Kang and Schuman, 1995, 1996; Patterson et al., 1996; Akaneya et al., 1997; Kang et al., 1997) as well as during refinement of synaptic connections (Cabelli et al., 1995, 1997; Riddle et al., 1995).

In conclusion, these experiments represent a new, reductionist approach to growth factor assays in cultures of CNS neurons, comparing the effects of specific factors on defined cell populations cultured alone with effects on the same cells in culture with their presynaptic partners. BDNF and NT-4 were each found to increase survival of Purkinje cells cultured alone. When Purkinje cells were cocultured with their presynaptic afferent granule cells, however, the same factors triggered non-NMDA receptormediated death. These observations support the idea that the neurotrophin and neurotransmitter systems are intimately linked and must be in proper balance for neuronal survival and normal development. Further experiments will explore the effects of neurotrophins on the later stages of differentiation, including spine development and synaptogenesis. 


\section{REFERENCES}

Akaneya Y, Tsumoto T, Kinoshita S, Hatanaka H (1997) Brain-derived neurotrophic factor enhances long-term potentiation in rat visual cortex. J Neurosci 17:6707-6716.

Altman J, Anderson WJ (1972) Experimental reorganization of the cerebellar cortex. I. Morphological effects of eliminating all microneurons with prolonged X-irradiation started at birth. J Comp Neurol 146:355-406.

Armengol JA, Sotelo C (1991) Early dendritic development of Purkinje cells in the rat cerebellum. A light and electron microscopic study using axonal tracing in in vitro slices. Brain Res 64:95-114.

Baird DH, Hatten ME, Mason CA (1992) Cerebellar target neurons provide a stop signal for afferent neurite extension in vitro. J Neurosci 12:619-634.

Baptista CA, Hatten ME, Blazeski R, Mason CA (1994) Cell-cell interactions influence survival and differentiation of purified Purkinje cells in vitro. Neuron 12:243-260.

Bonhoeffer T (1996) Neurotrophins and activity-dependent development of the neocortex. Curr Opin Neurobiol 6:119-126.

Cabelli RJ, Hohn A, Shatz CJ (1995) Inhibition of ocular dominance column formation by infusion of NT-4/5 or BDNF. Science 267:1662-1666.

Cabelli RJ, Allendoerfer KL, Radeke MJ, Welcher AA, Feinstein SC, Shatz CJ (1996) Changing patterns of expression and subcellular localization of TrkB in the developing visual system. J Neurosci 16:7965-7980.

Cabelli RJ, Shelton DL, Segal RA, Shatz CJ (1997) Blockade of endogenous ligands of TrkB inhibits formation of ocular dominance columns. Neuron 19:63-76.

Cassaccia-Bonnefil P, Carter BD, Dobrowsky RT, Chao MV (1996) Death of oligodendrocytes mediated by the interaction of nerve growth factor with its receptor p75. Nature 383:716-719.

Christakos S, Rhoten WB, Feldman SC (1987) Rat calbindin D28k: purification, quantitation, immunocytochemical localization, and comparative aspects. Methods Enzymol 139:534-551.

Cohen-Cory S, Fraser SE (1995) Effects of brain-derived neurotrophic factor on optic axon branching and remodelling in vitro. Nature 378:192-196.

Cohen-Cory S, Dreyfus CF, Black IB (1989) Expression of high- and low-affinity nerve growth factor receptors by Purkinje cells in the developing rat cerebellum. Exp Neurol 105:104-109.

Cohen-Cory S, Dreyfus CF, Black IB (1991) NGF and excitatory neurotransmitters regulate survival and morphogenesis of cultured cerebellar Purkinje cells. J Neurosci 11:462-471.

Cohen-Cory S, Escandon E, Fraser SE (1996) The cellular patterns of $\mathrm{BDNF}$ and trkB expression suggest multiple role for BDNF during Xenopus visual system development. Dev Biol 179:102-115.

Dugich-Djordjevic MM, Peterson C, Isono F, Ohsawa F, Widmer HR, Denton TL, Bennett GL, Hefti F (1995) Immunohistochemical visualization of brain-derived neurotrophic factor in the rat brain. Eur J Neurosci 7:1831-1839.

Ernfors P, Merlio J-P, Persson H (1992) Cells expressing mRNA for neurotrophins and their receptors during embryonic rat development. Eur J Neurosci 4:1140-1158.

Fernandez-Sanchez MT, Novelli A (1993) Basic fibroblast growth factor protects cerebellar neurons in primary culture from NMDA and nonNMDA receptor mediated neurotoxicity. FEBS Lett 335:124-131.

Fernandez-Sanchez MT, Novelli A (1995) Neurotrophins and excitotoxicity. Science 270:2019.

Figurov A, Pozzo-Miller LD, Olafsson P, Wang T, Lu B (1996) Regulation of synaptic responses to high-frequency stimulation and LTP by neurotrophins in the hippocampus. Nature 381:706-709.

Frade JM, Rodriguez-Tebar A, Barde Y-A (1996) Induction of cell death by endogenous nerve growth factor through its p75 receptor. Nature 383:166-168.

Galuske RAW, Kim D-S, Castren E, Thoenen H, Singer W (1996) Brain-derived neurotrophic factor reverses experience-dependent synaptic modifications in kitten visual cortex. Eur J Neurosci 8:1554-1559.

Gao W-Q, Zheng JL, Karihaloo M (1995) Neurotrophin-4/5 (NT-4/5) and brain-derived neurotrophic factor (BDNF) act at later stages of cerebellar granule cell differentiation. J Neurosci 15:2656-2667.

Ghosh A, Carnahan J, Greenberg ME (1994) Requirement for BDNF in activity-dependent survival of cortical neurons. Science 263:1618-1622.
Hatten ME (1985) Neuronal regulation of astroglial morphology and proliferation in vitro. J Cell Biol 100:384-396.

Hatten ME, Heintz N (1995) Mechanisms of neural patterning and specification in the developing cerebellum. Annu Rev Neurosci 18:385-408.

Henderson CE (1996) Role of neurotrophic factors in neuronal development. Curr Opin Neurobiol 6:64-70.

Hockberger PE, Tseng H-Y, Connor JA (1989) Development of rat cerebellar Purkinje cells: electrophysiological properties following acute isolation and in long-term culture. J Neurosci 9:2258-2271.

Hofer M, Pagliusi SR, Hohn A, Leibrock J, Barde Y-A (1990) Regional distribution of brain-derived neurotrophic factor mRNA in the adult mouse brain. EMBO J 9:2459-2464.

Kandel ER, Schwartz JH, Jessell TM (1995) Essentials of neural science and behavior. Norwalk, CT: Appleton \& Lange.

Kang H, Schuman EM (1995) Long-lasting neurotrophin-induced enhancement of synaptic transmission in the adult hippocampus. Science 267:1658-1662.

Kang H, Schuman EM (1996) A requirement for local protein synthesis in neurotrophin-induced hippocampal synaptic plasticity. Science 273:1402-1406.

Kang H, Welcher AA, Shelton D, Schuman EM (1997) Neurotrophins and time: different roles for TrkB signaling in hippocampal long-term potentiation. Neuron 19:653-664.

Katz LC, Shatz CJ (1996) Synaptic activity and the construction of cortical circuits. Science 274:1133-1138.

Koh J-Y, Gwag BJ, Lobner D, Choi DW (1995) Potentiated necrosis of cultured cortical neurons by neurotrophins. Science 268:573-575.

Larkfors L, Lindsay RM, Alderson RF (1994) Ciliary neurotrophic factor enhances the survival of Purkinje cells in vitro. Eur J Neurosci 6:1015-1025

Larkfors L, Lindsay RM, Alderson RF (1996) Ciliary neurotrophic factor enhances the survival of Purkinje cells in vitro. Eur J Neurosci 6:1015-1025.

Lein P, Johnson M, Guo X, Rueger D, Higgins D (1995) Osteogenic protein-1 induces dendritic growth in rat sympathetic neurons. Neuron 15:597-605.

Leingartner A, Heisenberg C-P, Kolbeck R, Thoenen H, Lindholm D (1994) Brain-derived neurotrophic factor increases neurotrophin-3 expression in cerebellar granule neurons. J Biol Chem 269:828-830.

Levine E, Dreyfus C, Black I, Plummer M (1995) Brain-derived neurotrophic factor rapidly enhances synaptic transmission in hippocampal neurons via postsynaptic tyrosine kinase receptors. Proc Natl Acad Sci USA 15:8074-8077.

Lindholm D, Castren E, Tsoulfas P, Kolbeck R, Berzaghi MP, Leingartner A, Heisenberg C-P, Tesarollo L, Parada LF, Thoenen H (1993) Neurotrophin-3 induced by tri-iodothyronine in cerebellar granule cells promotes Purkinje cell differentiation. J Cell Biol 122:443-450.

Lindholm D, Dechant G, Heisenberg C-P, Thoenen H (1993) Brainderived neurotrophic factor is a survival factor for cultured rat cerebellar granule neurons and protects them against glutamate-induced neurotoxicity. Eur J Neurosci 5:1455-1464.

Lindholm D, Hamner S, Zirrgiebel U (1997) Neurotrophins and cerebellar development. Perspect Dev Neurobiol 5:83-94.

Lo DC (1995) Neurotrophic factors and synaptic plasticity. Neuron 15:979-981.

Lohof AM, Ip NY, Poo M-m (1993) Potentiation of developing neuromuscular synapses by the neurotrophins NT-3 and BDNF. Nature 363:305-353.

Mariani J, Crepel F, Mikoshiba K, Changeux JP, Sotelo C (1977) Anatomical, physiological and biochemical studies of the cerebellum from reeler mutant mouse. Philos Trans R Soc Lond B Biol Sci 281:1-28.

McAllister AK, Lo DC, Katz LC (1995) Neurotrophins regulate dendritic growth in developing visual cortex. Neuron 15:791-803.

McAllister AK, Katz LC, Lo DC (1996) Neurotrophin regulation of cortical dendritic growth requires activity. Neuron 17:1057-1064.

McAllister AK, Katz LC, Lo DC (1997) Opposing roles for endogenous BDNF and NT-3 in regulating cortical dendritic growth. Neuron 18:767-78.

Meyer-Franke A, Kaplan MR, Pfrieger FW, Barres BA (1995) Characterization of the signalling interactions that promote the survival and growth of developing retinal ganglion cells in culture. Neuron 15:805-819.

Mount H, Dreyfus CF, Black IB (1993) Differential effects of neurotrophins on Purkinje cell survival. Soc Neurosci Abstr 19:661. 
Mount HTJ, Dreyfus CF, Black IB (1993) Purkinje cell survival is differentially regulated by metabotropic and ionotropic excitatory amino acid receptors. J Neurosci 13:3173-3179.

Mount HT, Dreyfus CF, Black IB (1994) Neurotrophin-3 selectively increases cultured Purkinje cell survival. NeuroReport 5:2497-2500.

Muller Y, Duperray C, Caruso F, Clos J (1994) Autocrine regulation of proliferation of cerebellar granule neurons by nerve growth factor. J Neurosci Res 38:41-55.

Patterson SL, Abel T, Deuel TAS, Martin KC, Rose JC, Kandel ER (1996) Recombinant BDNF rescues deficits in basal synaptic transmission and hippocampal LTP in BDNF knockout mice. Neuron 16:1137-1145.

Pozas E, Ballabriga J, Planas AM, Ferrer I (1997) Kainic acid-induced excitotoxicity is associated with a complex c-Fos and c-Jun response which does not preclude either cell death or survival. J Neurobiol 33:232-46.

Prakash N, Cohen-Cory S, Frostig RD (1996) Rapid and opposite effects of BDNF and NGF on the functional organization of the adult cortex in vivo. Nature 381:702-706.

Privat A, Drian MJ (1976) Postnatal maturation of rat Purkinje cells cultivated in the absence of two afferent systems: an ultrastructural study. J Comp Neurol 166:201-244.

Rakic P (1975) Role of cell interaction in development of dendritic patterns. Adv Neurol 12:117-134.

Riddle DR, Lo DC, Katz LC (1995) NT-4 mediated rescue of lateral geniculate neurons from effects of monocular deprivation. Nature 378:189-191.

Rocamora N, Garcia-Ladona FJ, Palacios JM, Mengod G (1993) Differential expression of brain-derived neurotrophic factor, neurotrophin-3, and low-affinity nerve growth factor receptor during the postnatal development of the rat cerebellar system. Mol Brain Res 17:1-8.

Sawai H, Clarke DB, Kittlerova P, Bray GM, Aguayo AJ (1996) Brainderived neurotrophic factor and neurotrophin-4/5 stimulate growth of axonal branches from regenerating retinal ganglion cells. J Neurosci 16:3887-3894.

Schilling K, Dickinson MH, Connor JA, Morgan JI (1991) Electrical activity in cerebellar cultures determines Purkinje cell dendritic growth patterns. Neuron 7:891-902.

Schuman EM (1997) Synapse specificity and long-term information storage. Neuron 18:339-42.
Schwartz PM, Borghesani PR, Levy RL, Pomeroy SL, Segal RA (1997) Abnormal cerebellar development and foliation in $B D N F-/-$ mice reveals a role for neurotrophins in CNS patterning. Neuron 19:269-281.

Segal RA, Pomeroy SL, Stiles CD (1995) Axonal growth and fasciculation linked to differential expression of BDNF and NT3 receptors in developing cerebellar granule cells. J Neurosci 15:4970-4981.

Snider WD, Lichtman JW (1996) Are neurotrophins synaptotrophins? Mol Cell Neurosci 7:433-442.

Sotelo C, Arsenio-Nunes ML (1976) Development of Purkinje cells in the absence of climbing fibers. Brain Res 111:389-395.

Stoop R, Poo M-m (1996) Synaptic modulation by neurotrophic factors: differential and synergistic effects of brain-derived neurotrophic factor and ciliary neurotrophic factor. J Neurosci 16:3256-3264.

Thoenen H (1995) Neurotrophins and neuronal plasticity. Science 270:593-598.

Tokita Y, Bessho Y, Masu M, Nakamura K, Nakao K, Katsuki M, Nakanishi S (1996) Characterization of excitatory amino acid neurotoxicity in $N$-methyl-D-aspartate receptor-deficient mouse cortical neuronal cells. Eur J Neurosci 8:69-78.

Torres JM, Javier Naves F, Esteban I, Del Velle ME, Vega JA (1995) Neurotrophin receptor proteins immunoreactivity in the rat cerebellar cortex as a function of age. Mech Ageing 83:1-9.

von Bartheld CS, Kinoshita Y, Prevette D, Yin QW, Oppenheim RW, Bothwell M (1994) Positive and negative effects of neurotrophins on the isthmo-optic nucleus in chick embryos. Neuron 12:639-654.

Wassef M, Zanetta JP, Brehier A, Sotelo C (1985) Transient biochemical compartmentalization of Purkinje cells during early cerebellar development. Dev Biol 111:129-137.

Weber A, Schachner M (1984) Maintenance of immunocytologically identified Purkinje cells from mouse cerebellum in monolayer culture. Brain Res 311:119-130.

Wheeler EF, Bothwell M (1992) Spatiotemporal patterns of expression of NGF and the low-affinity NGF receptor in rat embryos suggest functional roles in tissue morphogenesis and myogenesis. J Neurosci 12:930-945.

Yan Q, Johnson EM (1988) An immunohistochemical study of the nerve growth factor receptor in developing rats. J Neurosci 8:3481-3498.

Zhou XF, Rush RA (1994) Localization of neurotrophin-3-like immunoreactivity in the rat central nervous system. Brain Res 643:162-172. 